\title{
STUDI KELAYAKAN JALAN PERKERASAN KAKU DAN PERKERASAN LENTUR
}

\author{
Lia Lailla Nurjamilah, Nanang Wardi \\ Teknik Sipil Fakultas Teknik Universitas Majalengka \\ Dzia.rifqi@ymail.com
}

\begin{abstract}
Abstrak
Pembangunan dan pengembangan infrastruktur jalan, khususnya dalam proses penentuan proyek jalan, umumnya disusun berdasarkan skala kebutuhan dan kemendesakan (need and urgency) sebagaimana tercantum dalam Daftar Usulan Rencana Proyek (DURP). hasil analisis konstruksi beton lebih layak diterapkan untuk konstruksi jalan K.H Abdul Halim Majalengka (Bunderan Munjul). Dari 8 faktor penilai, konstruksi beton unggul pada 4 faktor yaitu daya tahan terhadap cuaca, daya tahan terhadap pergerakan tanah, daya tahan terhadap lalu lintas dan jangka waktu perawatan dengan tingkat keunggulan rata-rata 6 kali dibanding konstruksi aspal. Sedangkan konstruksi aspal unggul pada faktor-faktor kenyamanan permukaan jalan, kemudahan pelaksanaan pembangunan, ketersediaan sumberdaya dan tekhnologi dan biaya dengan tingkat keunggulan rata-rata 4 kali dibaning konstruksi beton. Dari analisis perbandingan yang melibatkan seluruh faktor yng ditinjau diketahui bahwa jalan beton rata-rata lebih unggul dibanding dengan jalan aspal. Hal ini ditunjukan dari hasil pembobotan untuk konstruksi beton mencapai 2,62 sementara bobot unuk konstruksi aspal hanya sebesar 2,19.
\end{abstract}

Kata kunci : Infrastruktur, Jalan Aspal, Jalan Beton

\section{PENDAHULUAN}

\section{A. Latar Belakang}

Pembangunan dan pengembangan infrastruktur jalan ,khususnya dalam proses penentuan proyek jalan, umumnya disusun berdasarkan skala kebutuhan dan kemendesakan (need andurgency) sebagaimana tercantum dalam Daftar Usulan Rencana Proyek ( URP ). Akan tetapi, kenyataan dilapangan menunjukan bahwa banyak sekali ketidaksesuaian antara DURP dengan rencana proyek yang sudah disetujui sebagaimana tercantum dalam Daftar Isian Proyek (DIP). Salah satu faktor yang diduga menyebabkan kondisi diatas adalah terlalu dominannya para pengambil kebijakan (decisionmaker) dalam menetapkan penanganan proyek jalan tanpa didasari atas pertimbangan-pertimbangan obyektif seperti unsur kemendesakan dan kebutuhan. Akibatnya, banyak proyek yang seharusny amenggunakan system tertentu atau dalam skala prioritas tertentu dapat berubah ke sistem yang lain atau prioritas lain.

\section{B. Maksud Dan Tujuan Penelitian}

Maksud studi ini adalah mengkaji penerapan metode Analytical Hierarchy Process (AHP) untuk menilai kelayakan konstruksi jalan beton dibanding jalan aspal untuk kasus jalan Bundaran Munjul. Sedangkan tujuannya secara spesifik adalah:

a) Menilai secara kualitatif kelayakan jalan konstruksi beton berdasarkan faktor-faktor teknis dan non teknis.

b) Menilai secara kualitatif kelayakan jalan konstruksi aspal berdasarkan faktorfactor teknis dan nonteknis.

c) Membandingkan secara kualitatif kelayakan jalan antara konstruksi beton 
dan konstruksi aspal berdasarkan faktorfaktor teknis dan non teknis dengan menggunakan metode AHP.

\section{TINJAUAN PUSTAKA}

\section{A. Konstruksi Jalan Aspal}

Konstruksi jalan aspal atau disebut juga perkerasan fleksibel (flexible pavement) merupakan perkerasan yang menggunakan aspal sebagai bahan ikat pada lapisan permukaan dan atau lapisan pondasi atas atau ATB (asphalt treated base). Nilai modulus elastisitas untuk konstruksi aspal umunya sekitar 4.000 Mpa, suatu angka yang cukup kecil yang menyebabkan konstruksi aspal bersifat cukup lentur.

Konstruksi aspal yang dikenal dan sudah umum digunakan sampai saat ini diantaranya adalah: a. Perkerasan lentur konvensional ( conventional flexible pavement ) yang terdiri dari lapisan dasar, lapisan pondasi atas dan lapisan permukaan

b. Perkerasan lentur non konvensional (full-depth asphalt pavement)

Lapisan lentur non konvensional merupakan konstruksi aspal dimana lapisan campuran aspal langsung diletakan diatas tanah dasar atau tanah dasar yang sudah dilakukan pemadatan ( treated subgrade ).

Bentuk umum dari konstruksi lentur aspal seperti tampak dalam gambar1.

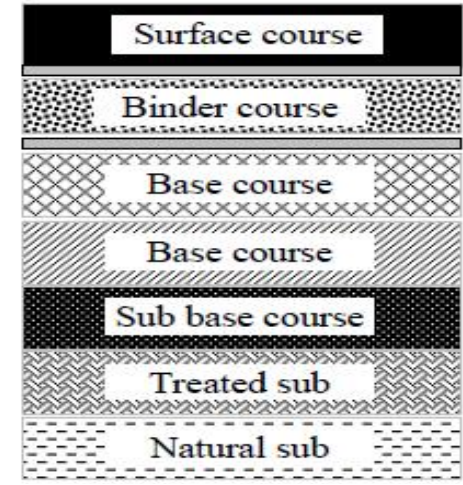

(a) perkerasan

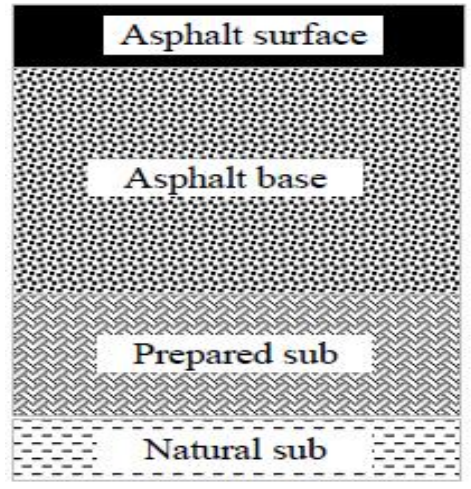

(b) Perkerasan non

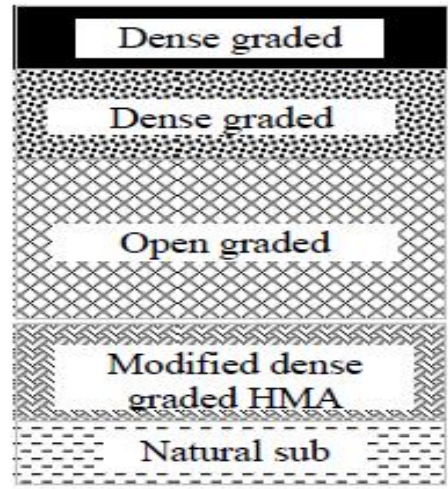

(c) PerkerasanCRAM

Sumber : Bina Marga dan Cipta Karya, 2000

Gambar 1. Potongan melintang konstuksi lentur aspal

\section{B. Konstruksi Jalan Beton}

Konstruksi jalan beton atau disebut juga perkerasan beton semen merupakan perkerasan yang menggunakan semen sebagai bahanikat sehingga tingkat kekakuan yang relative cukup tinggi khususnya bila dibandingkan dengan perkerasan aspal ( Aly, M.A.,2004 ). Nilai modulus elastisitas untuk konstruksi beton sekitar 10kali lipat disbanding dengan moduluselastisitas perkerasan aspal. diIndonesia dikenal beberapa jenis konstruksi beton yang sudah umum dipakai, yaitu: a. Perkerasan betonsemen "tanpatulangan dengansambungan" atau jointed un reinforced concrete pavement.

b. Perkerasan beton semen "dengan tulangan dengan sambungan" atau jointed reinforced concrete pavement.

c. Perkerasan beton semen "bertulang tanpa sambungan" atau continuosly reinforced concretepavement.

d. Perkerasan betonsemen "prategang" atau prestressed concrete pavement.

e. Perkerasan beton semen "bertulang fiber" atau fiberreinforced concrete pavement. 
Bentuk umum dari konstruksi beton terdiri atas 3 lapisanya itu lapisan tanah (cementtreated subbase), dan lapisan beton (Gambar2).

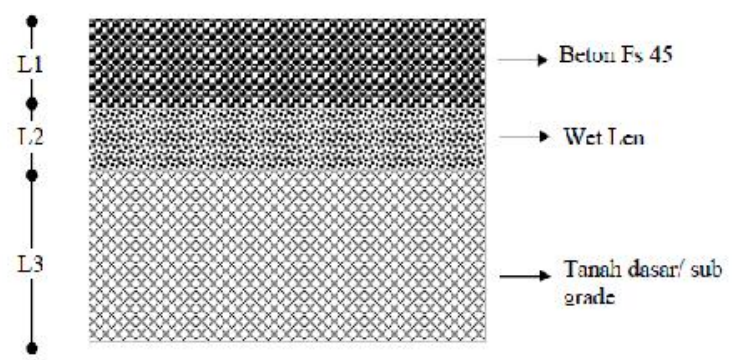

Sumber: Bina Marga dan Cipta Karya,2000

Gambar 2. Potongan melintang konstuksi beton tipikal

Performansi Jalan Sesuai dengan fungsi jalan sebagai prasarana pergerakan lalulintas, makajalan dapat dinilai dari segi kualitas kinerjanya atau performansi. Diantara hal-hal yang berkaitan dengan performansi misalnya daya tahan, nilai ekonomis, umurrencana, kenyamanan, fleksibilitas, aplikabilitas, dsb. Setiap komponen performansi turut mempengaruhi dalam kualitas pelayanan jalan terhadap lalulintas.
a. Daya tahan
b. Nilai ekonomis
c. Umur rencana
d. Kenyamanan
e. Fleksibilitas
f. Aplikabilitas

dasar ( subgrade ), lapisan lantai kerja

\section{Metode Analytic Hierarchy Process (AHP)}

Proses hirarki analitis atau disingkat AHP ( Saaty,2000 ) adalah suatu pendekatan pengambilan keputusan yang dirancang untuk membantu pencarian solusi dari berbagai permasalahan multikriteria yang kompleks dalam sejumlah ranah aplikasi. Metoda ini telah didapati sebagai pendekatan yang praktis dan efektif

yang dapat mempertimbangkan keputusan yang tidak tersusun dan rumit ( Partovi, 1994 ).

\section{Pembentukan Hirarki Struktural}

Langkah ini bertujuan memecah suatu masalah yang kompleks disusun menjadi suatu bentuk hirarki. Suatu struktur hirarki sendiri terdiri dari elemen-lemen yang dikelompokan dalam tingkatan-tingkatan (level). Dimulai dari suatu sasaran pada tingkatan puncak, selanjutnya dibangun tingkatan yang lebih rendah yang mencakup kriteria, subkriteria dan seterusnya sampai pada tingkatan yang paling rendah. Sasaran atau keseluruhan tujuan keputusan merupakan puncak dari tingkat hirarki. Kriteria dan subkriteria yang menunjang sasaran berada ditingkatan tengah. Dan, alternatif atau pilihan yang hendak dipilih berada pada level paling bawah dari struktur hirarki yang ada.

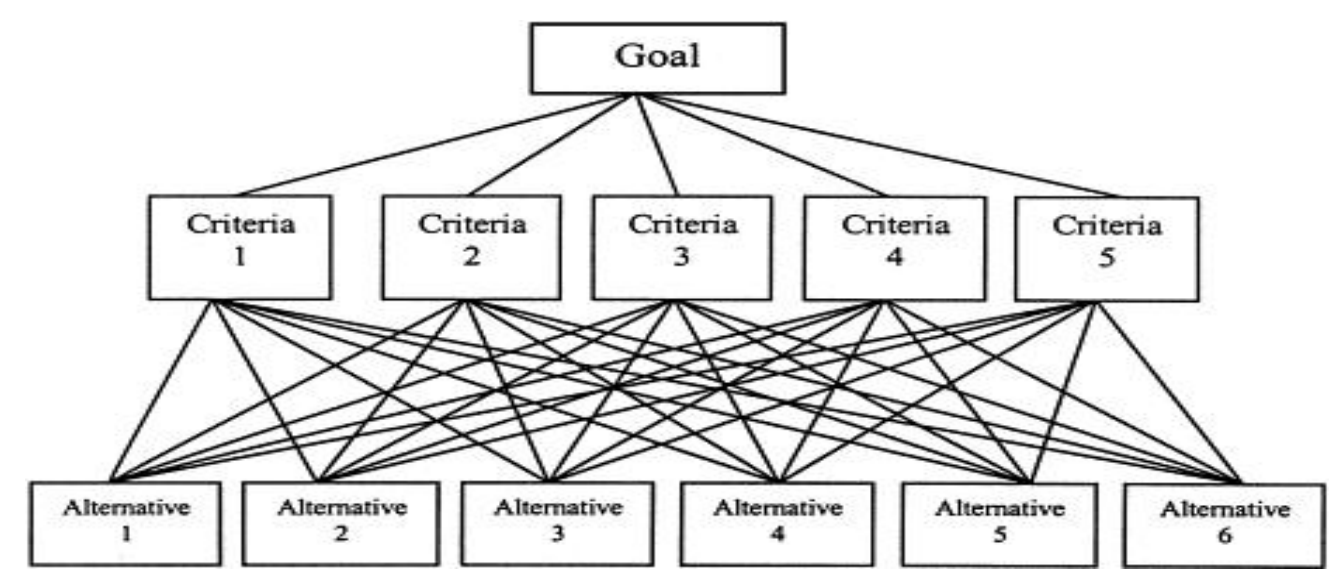

Sumber : Saaty, 2000

Gambar 3.. Model AHP secara umum 


\section{METODE PENELITIAN}

Sebagai studi kasus, dilakukan pengumpulan data tentang nilai kepentingan faktor-faktor yang berpengaruh dalam hal melakukan pengamatan langsung di jalan Bunderan Munjul. Data tersebut berupa data perbandingan berpasangan dengan skala 1 9. Data-data yang terkumpul tersebudiolah dengan metode AHP. Data tersebut sebelumnya diuji terlebih dahulu inconsistencyratio-nya (CR) yaitu data yang CR- nya kurang dari $10 \%$ yang dianggap konsisten.

\section{A. Analisis Perbandingan dengan Metode AHP}

Penelitian dalam studi ini fokus pada perumusan suatu model berbasis AHP untuk menilai jenis konstruksi jalan antara beton dengan aspal yang memiliki kelayakan yang paling baikdi antara keduanya. Sekalipun demikian, konsep pengembangan dan struktur model yang nantinya dikembangkan, akan dapat diberlakukan pula bagi pemilihan jenis konstruksi jalan yang lain, jika dikehendaki. Secara mendasar, ada tiga langkah dalam model AHP, yaitu: membangun hirarki, penilaian, dan sintesis prioritas.

\section{B. Pembentukan Hirarki}

Dalam bagian ini diperkenalkan suatu pendekatan konseptual untuk penilaian kelayakan jenis konstruksi jalan dengan menggunakan model AHP. Dalam model yang diusulkan dalamstudi ini, setidaknya terdapat 5 level hirarki sebagai berikut:

1. Level I : Sasaran dari keputusan yang akan diambil ditempatkan pada puncak hirarki. Dalam hal ini sasaran yang dimaksud adalah "memilih kelayakan konstruksi jalan bagi jalan K.H. Abdul Halim Majalengka".

2. Level II : Pada tingkatan kedua, diajukan kriteria-kriteria penilaian dari sisi teknis konstruksi jalan yang dapat menunjukan kualitas atau tingkat pelayanan jalan. Kriteria-keriteria dimaksud terdiri dari daya tahan terhadap cuaca, daya tahan terhadap pergerakan tanah dan daya tahan terhadap perubahan lalu linta

3. Level III : Pada tingkatan ketiga, diajukan sub kriteria yang berkaitan dengan pelayanan jalan seperti kenyamanan, jangka waktu perawatan, kemudahan pelaksanaan, dan ketersediaan sumber daya.

4. Level IV : Pada level keempat, diajukan sub kriteria yang berkaitan dengan biaya pengadaan atau pembangunan.

5. Level V : Pada level V, diajukan alternative jenis konstruksi jalan yang dapat diaplikasikan di Jalan K.H. Abdul Halim Majalengka ( Bunderan Munjul) yaitu Konstruksi Beton dan Konstruksi aspal.

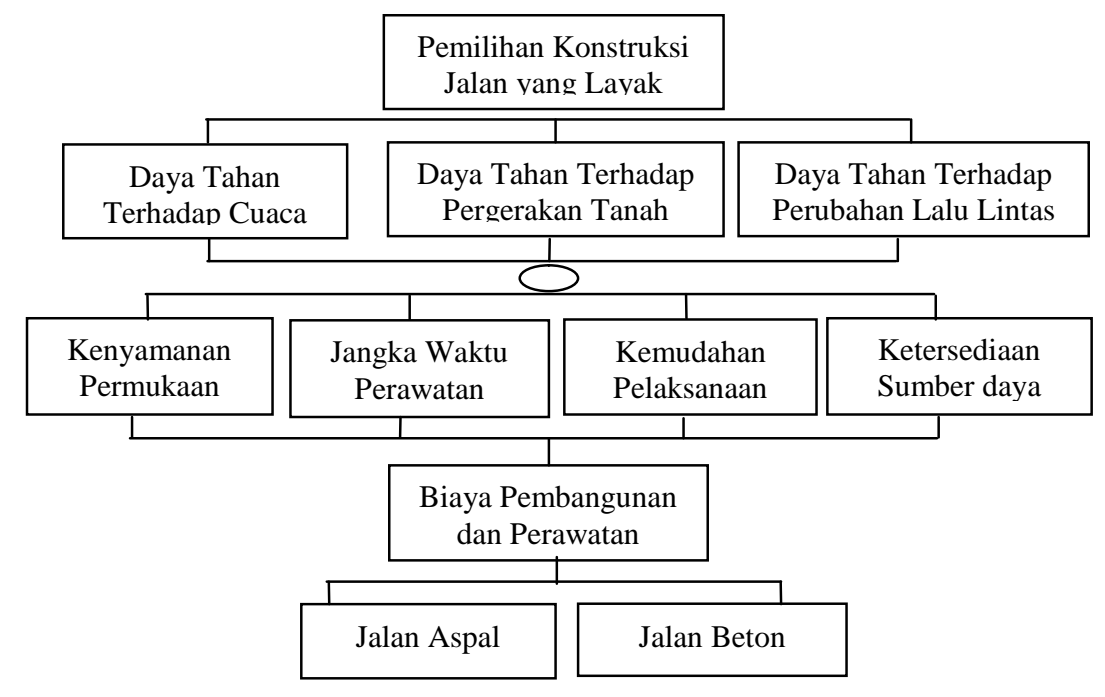

Gambar 4. Struktur Hirarki AHP Untuk Analisis Pemilihan Kelayakan Konstruksi Jalan 


\section{PEMBAHASAN}

\section{A. Faktor Teknis yang Paling Berpengaruh}

Hasil pembobotan faktor teknis menunjukan bahwa diantara ketiga faktor teknis yangada, factor yang dianggap paling dominan untuk mengukur kelayakan antara jalan aspal dan jalan beton adalah factor daya terhadap cuaca $(1,52)$. Faktor kedua adalah Daya tahan terhadap pergerakan tanah $(1,10)$ dan yang terakhir adalah Daya tahan terhadap perubahan lalulintas (0,52). Hasil ini mengisyaratkan bahwa responden melihat daya tahan terhadap cuaca begitu penting terhadap kelayakan suatu jalan terutama karena perubahan cuaca umumnya sering menjadi pemicu kerusakan suatu konstruksi (misalnya akibat hujan, genangan, dsb ) lebih banyak dibanding factor lain

.Tabel 1 . Hasil Bobot Untuk Faktor Teknis

\begin{tabular}{|r|l|c|}
\hline No. & \multicolumn{1}{|c|}{ Faktor } & Bobot \\
\hline 1. & Daya tahan terhadap cuaca & 1.52 \\
\hline 2. & Daya tahan terhadap pergerakan tanah & 1.10 \\
\hline 3. & Daya tahan terhadap perubahan lalu lintas & 0.52 \\
\hline
\end{tabular}

Sumber: Hasil analisis

Sementara yang menjadi factor minor adalah factor daya tahan terhadap perubahan lalu lintas.

\section{B. Faktor Non Teknis yang Paling Berpengaruh}

Sementara itu, untuk faktor nonteknis yang paling berpengaruh untuk menilai kelayakan suatu jalan ditempati oleh factor jangka waktu perawatan dan ketersediaan sumber daya $(5,46)$. Jangka waktu perawatan berkaitan dengan cepat atau lamanya suatu konstruksi membutuhkan perbaikan.Sementara ketersediaan sumber daya terutama berkaitan dengan ketersediaan dana. Kedua faktor tersebut dominan mengindikasikan bahwa 1) sesedikit mungkin perawatan dan perbaikan yang dilakukan berarti konstruksi jalan dianggap lebih baik, dan 2) ketersediaan sumber daya khususnya dana merupakan factor yang sangat menentukan suatu konstruksi dipilih untuk dibangun atau tidak. Karena pada dasarnya dana selalu menjadi kendala terutama ditengahanggaran pembangunan jalan yang terbatas di Indonesia.

Tabel 2. Bobot Untuk Faktor Non Teknis

\begin{tabular}{|l|l|c|}
\hline No. & \multicolumn{1}{|c|}{ Faktor } & Bobot \\
\hline 1. & Kenyamanan permukaan jalan & 3.79 \\
\hline 2. & Kemudahan pelaksanaan pembangunan & 2.09 \\
\hline 3. & Jangka waktu perawatan jalan & 5.46 \\
\hline 4. & Ketersediaan sumberdaya dan tekhnologi & 5.46 \\
\hline
\end{tabular}

Sumber: Hasil analisis

Sementara factor lain yang penting diperhatikan adalah masalah kenyamanan permukaan konstruksi jalan $(3,79)$. Faktor ini penting karena berkaitan dengan kenyamanan pengguna setelah konstruk siselesai dibangun. Dalam studi ini, factor kenyamanan juga lebih diunggulkan disbanding factor kemudahan dalam pembangunan (2.09). 


\section{Kelayakan Jalan berdasarkan Faktor Teknis dan Non Teknis}

Setelah menilai faktor-faktor apa yang paling dipertimbangkan dalam menilai suatu kelayakan jalan, selanjutnya penting dinilai seberapa jauh factor tersebut menentukan pilihan konstruksi. Penilaian kelayakan jalan dinilai berdasarkan gabungan antara faktor teknis, non teknis dan biaya. Hasil penilaian setiap factor dapat ditelusuri berdasarkan pembobotan sebagai mana terkandung dalam vector VK 1 sampai VK 7dan dirangkum dalam Tabel 3. Dari Tabel 3, dapat ditarik beberapa pernyataan berikut:

1) Dalam hal Daya tahan terhadap cuaca, beton 6 kali lebih unggul disbanding aspal.

Tabel. 3. Hasil Bobot Untuk Semua Faktor

\begin{tabular}{|r|l|c|c|}
\hline \multirow{2}{*}{ No. } & \multicolumn{2}{|c|}{ Faktor } & \multicolumn{2}{c|}{ Bobot } \\
\cline { 3 - 4 } & & Beton & Aspal \\
\hline 1 & Daya tahan terhadap cuaca & 3.40 & 1.73 \\
\hline 2 & Daya tahan terhadap pergerakan tanah & 3.40 & 1.73 \\
\hline 3 & Daya tahan terhadap perubahan lalulintas & 3.40 & 1.73 \\
\hline 4 & Kenyamanan permukaan jalan & 0.67 & 3.36 \\
\hline 5 & Kemudahan pelaksanaan pembangunan & 0.67 & 3.36 \\
\hline 6 & Jangkawaktu perawatan jalan & 3.40 & 1.73 \\
\hline 7 & Ketersediaan sumberdaya & 3.40 & 1.73 \\
\hline
\end{tabular}

Sumber: Hasil analisis

\section{Hasil Penilaian Akhir}

Penilaian akhir dari analisis dapat ditelusuri dari pembobotan sebagaimana tercantum dalam vector VA 21 atau sebagaimana yang ditampilkan dalam Tabel 4.58. Dari table terlihat bahwa konstruksi beton secara keseluruhan lebih baik
2) Dalam hal Daya tahan terhadap pergerakan tanah, beton 6 kali lebih unggul disbanding aspal.

3) Dalam hal Daya tahan terhadap perubahan lalulintas, beton 5 kali lebih unggul dibanding aspal.

4) Dalam hal Kenyamanan permukaan jalan, aspal 5 kali lebih unggul dibanding beton.

5) Dalam hal Kemudahan pelaksanaan pembangunan, aspal 5 kali lebih unggul disbanding beton.

6) Dalam hal Jangka waktu perawatan, beton 5,5 kali lebih unggul disbanding aspal.

7) Dalam hal Ketersediaan sumber daya, aspal 2 kali lebih unggul disbanding beton. 


\section{PENUTUP}

\section{A. Kesimpulan}

Dari analisis yang telah dilakukan, dapat ditarik beberapa poin kesimpulan sebagai berikut:

1. Bahwa berdasarkan analisis AHP, diketahui factor teknis yang mempunyai bobot tertinggi adalah faktor daya tahan terhadap cuaca $(1,52)$. Ini mengindikasikan bahwa factor daya tahan terhadap cuaca dianggap factor teknis yang paling penting untuk menilai kelayakan suatu jalan berdasarkan penilaian responden.

2. Bahwa berdasarkan analisis AHP, diketahui faktor non teknis yang mempunyai bobot tertinggi adalah factor ketersediaan sumber daya teknologi dan Jangka waktu perawatan $(5,46)$. Ini mengindikasikan bahwa factor ketersediaan sumber daya merupakan factor non teknis yang paling dipertimbangkan dalam pemilihan kelayakan jalan berdasarkan penilaian responden.

3. Dari 8 faktor penilai, konstruksi beton unggul pada 4 faktor yaitu daya tahan terhadap cuaca, daya tahan terhadap pergerakan tanah, daya tahan terhadap lalu lintas dan jangka waktu perawatan dengan tingkat keunggulan rata-rata 6 kali disbanding konstruksi aspal. Sedangkan konstruksi aspal unggul pada faktor-faktor kenyamanan permukaan jalan, kemudahan pelaksanaan pembangunan, ketersediaan sumberdaya dan tekhnologi dan biayadengan tingkat keunggulan rata-rata 4 kali dibaning konstruksi beton.

4. Dari analisis perbandingan yang melibatkan seluruh factor yng ditinjau diketahui bahwa jalan beton rata-rata lebih unggul disbanding dengan jalan aspal. Hal ini ditunjukan dari hasil pembobotan untuk konstruksi beton mencapai 2,62 sementara bobot unuk konstruksi aspal hanya sebesar 2,19.

\section{B. Rekomendasi}

Dari analisis dan kesimpulan yang ada, selanjutnya dapat diberikan beberapa rekomendasi sebagai berikut:

1. Perubahan konstruksi dari aspal ke beton sebagaimana saat ini sedang dilakukan di jalan K. H Abdul Halim (Bunderan Munjul) Kabupaten Majalengka perlu didukung mengingat dalam banyak hal konstruksi beton lebih layak disbanding konstruksi aspal seperti kesimpulan dari study ini.

2. Data untuk metode AHP dalam studi ini mengandalkan penilaian responden terhadap faktor-faktor yang diajukan. Karena penilaian akan sangat bervariasi antar satu dengan yang lainnya (sebagaimana ditunjukan dalam distribusi frekuensi dat\$), maka penambahan jumlah responden dengan sumber yang semakin luas melibatkan para ahli perlu dilakukan guna menjaga konsistensi data.

\section{DAFTAR PUSTAKA}

Aly M. A., (2004). Tekhnologi Perkerasan Jalan Beton Semen 2004, Yayasan Pengembang Tekhnologi dan Manajemen, Jakarta Barat, Jakarta.

Atthirawong, W. and B. Mac Carthy, (2005). An Application of the Analytica Hierarchy Process to International Decision-Making, Schools of Mechanic, Materials, Manufacturing, Engineering and Management, University of Nottingham, USA.

Huang, Y. H., (1993). Pavement Analysis and Design, Prentice Hall, Englewood Cliff, New Jersey, USA.

Partovi, F. Y., (1994). Determining What to Bencmark: An Analytical Hierarchy Process Approach, International Journal of Operations and Production Management, 14 (6), pp $55-39$. 
Rahim, I. R. dan Tri Harianto, (2002). Studi Kelayakan Jalan Konstruksi Beton di Perumahan Bukit Tamalanrea, Makasar, Makalah Seminar, Fakultas Teknik Jurusan Teknik Sipil, Universitas Hasanuddin, Makasar.

Saaty, T. L., (1990). Fundamentals of Decision Making and Priority Theory, $2^{\text {nd }}$ Edition, Pittsburgh, PA:RWS Publication.

Teknomo, K., et. Al., (2005). Penggunaan Metode Analytic Hierarchy Process dalam Menganalisa FaktorFaktoryang Mempengaruhi Pemilihan Moda ke Kampus, Tesis Magister, Fakultas Teknik Jurusan Teknik Sipil, Universitas Kristen Petra, Surabaya. 